\title{
JUURNAL_RU
}

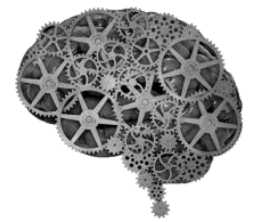

COMPANY GROUP "INTELLEKT"

\author{
Галышев А.Б. \\ МАДИ \\ Москва, Россия
}

doi: 10.18411/lj2016-6-1-07

\section{Обоснование необходимости использования асфальта с добавлением резиновой крошки при создании объектов велотранспортной инфраструктуры}

Велосипедное движение является одним из наиболее рациональных решений социальных и экологических проблем, связанных с процессом автомобилизации. Велосипед не производит вредных выбросов и не создает шума, требует значительно меньше эксплуатационных затрат, чем автомобиль, езда на нем способствует укреплению здоровья и др. Однако перед развитием велосипедного движения в городах России стоит ряд проблем. И одна из них недостаток объектов велотранспортной инфраструктуры (ВТИ) [1]. Выделяется 6 типов ВТИ: 1 - изолированная велосипедная дорожка, 2 - обособленная велосипедная дорожка, 3 - велосипедная полоса, 4 - велопешеходная дорожка с разделением пешеходного и велосипедного движения, 5 - велопешеходная дорожка без разделения пешеходного и велосипедного движения, 6 «велосипедная улица» (совместное движение автотранспорта и велосипедов со скоростью не более 30 км/ч). Последние 3 мероприятия особенно актуальны в исторических центрах городов, где ширина улиц не позволяет обеспечить приемлемые условия движения для всех участников дорожного движения. В то же время именно там с наибольшей остротой сказываются негативные последствия процесса автомобилизации, а потому необходимость развития велосипедного движения особенно очевидна. 
Поскольку велотранспортные системы являются важными и самостоятельными компонентами улично-дорожной сети городов, к ним должны предъявляться достаточно жесткие требования качества. В частности покрытия объектов ВТИ должны быть твердыми и ровными. Поэтому наиболее предпочтительным материалом для них является асфальтобетон [1]. Однако обычный асфальтобетон не лишен недостатков: склонен к образованию трещин из-за повышенной эксплуатационной нагрузки и перепадов температуры, что снижает срок службы покрытия, даже при незначительном увлажнении обладает высокой скользкостью, что ведет к увеличению риска дорожно-транспортного происшествия (ДТП). Исследованиями многих авторов установлено, что повышение противогололедных свойств и устойчивости к колееобразованию асфальтобетонных покрытий возможно введением в состав асфальтобетона резиновой крошки [2].

Резиновая крошка — это частицы измельченной резины разнообразной величины и формы, которые сохраняют молекулярную структуру и эластомерные свойства исходной резины. Главное достоинство этого материала состоит в том, что для его изготовления используется вторсырье из полимерных материалов, прежде всего изношенные шины. Проблема утилизации изношенных автомобильных шин имеет важное экономическое и экологическое значение. Только в нашей стране ежегодно выходят из строя более 1 млн. тонн шин и других резино-технических изделий. Кроме того, образуется большое количество производственных резиновых отходов. Прирост их объема составляет около 3\% в год, т.е. идет постоянное накопление не переработанного вторсырья. Некоторая часть отходов, особенно из ценных видов резин, годами хранится на складах, остальная часть отходов подвергается, в лучшем случае, захоронению или сжигается, нанося тем самым значительный и долговременный ущерб окружающей среде [3].

Одним из потенциальных направлений использования продуктов переработки изношенных шин является производство мелкодисперсной 
резиновой крошки и ее использование в дорожном строительстве [4,5]. Таким образом, применение резиновой крошки позволяет решить сразу две проблемы: очистить экосистемы от свалок и улучшить эксплуатационные свойства дорожных покрытий [6].

Асфальтобетон с добавлением резиновой крошки имеет ряд преимуществ по сравнению с обычным. В таблице 1 представлены полученные экспериментальным путем сравнительные характеристики асфальтобетонов на композиционном вяжущем БИТРЭК и традиционных горячих асфальтобетонных смесей [2].

По данным таблицы 1 видно, что асфальтобетон с добавлением резиновой крошки обладает улучшенными характеристиками по сравнению с традиционными типами. Асфальтовые покрытия с резиновой крошкой получаются более гибкими, благодаря чему срок их службы возрастает на несколько лет. Повышенная устойчивость к процессам растяжения и сдвига позволяет замедлить образование колеи, а также избавиться от сквозного сетчатого растрескивания дорожного покрытия [2]. При этом снижаются затраты на ремонтные работы. Данное свойство на первый взгляд приносит большую пользу при эксплуатации автомобильных дорог, так как велосипедное и пешеходное движение оказывают значительно меньшее механическое воздействие на дорожное покрытие. Однако следует помнить, что толщина покрытия у велосипедных и пешеходных дорожек обычно меньше, чем у автомобильных. И при этом ему часто приходится выдерживать повышенные нагрузки, например при движении дорожной техники. Кроме того трещиностойкость покрытия становится определяющим фактором на «велосипедных улицах», где велосипеды двигаются совместно с автомобилями. A поскольку велосипедисты являются уязвимыми участниками дорожного движения, отсутствие трещин на дороге может стать определяющим фактором при выборе ими маршрута движения. 
Таблица 1

Сопоставление характеристик разных типов асфальтобетона

\begin{tabular}{|c|c|c|c|}
\hline Показатель & Асфальтобетон БИТРЭК & $\begin{array}{c}\text { Асфальтобетон БНД } \\
60 / 90\end{array}$ & $\begin{array}{c}\text { Требования ГОСТ 9128- } \\
97\end{array}$ \\
\hline $\begin{array}{c}\text { Прочность при сжатии }\left(0^{\circ}\right), \\
\text { МПа }\end{array}$ & 10,0 & 13,7 & $9,0-11,0$ \\
\hline $\begin{array}{c}\text { Прочность на сдвиг } \\
\text { раскол) при 0 }{ }^{\circ} \text { С МПа }\end{array}$ & 2,7 & 3,6 & $0,85-1,0$ \\
\hline Водостойкость & 1,0 & 0,8 & $0,75-0,9$ \\
\hline $\begin{array}{c}\text { Водостойкость при } \\
\text { длительном водонасыщении }\end{array}$ & 0,98 & 0,65 & $1,5-4,0$ \\
\hline Водонасыщение, $\%$ & 1,7 & 1,8 & \\
\hline
\end{tabular}

Кроме того, как видно из таблицы 1, резиновая крошка способствует улучшению дренажных свойств дороги, что оказывает благотворное влияние на снижение износа дорожного полотна от воздействия атмосферных осадков. А так как резиновая крошка выступает в качестве компонента наполнителя, такая дорога не теряет мелкозернистые материалы под воздействием солнца, как обычный асфальт. Оба упомянутых качества создают положительный эффект, независимый от назначения дороги, поэтому являются важными аргументами в пользу применения асфальта с добавлением резиновой крошки для создания объектов ВТИ.

Другим важным преимуществом асфальтобетона с добавлением резиновой крошки является повышенная устойчивость к перепаду температур. Это свойство особенно важно для климатических условий нашей страны с резкими перепадами температур, как в течение суток, так и в течение года. С одной стороны, за счет повышения пластичности и упругости покрытия при высоких температурах снижается вероятность возникновения следов от транспортных средств, а впоследствии и колеи. С другой стороны, при низких температурах такие покрытия отличаются меньшей хрупкостью и более устойчивы к появлению трещин. Таким образом, именно климатический фактор в нашей стране становится определяющим для оценки целесообразности применения резиновой крошки в дорожном строительстве. Особенно в создании объектов ВТИ, так как велотранспорт оказывает относительно слабое механическое 
воздействие на дорожное покрытие, и главных фактором его долговечности становится природно-климатический.

К тому же сила сцепления льда с поверхностью асфальта, модифицированного резиновой крошкой, значительно ниже, чем с поверхностью традиционного асфальтобетона [2]. Введение резиновой крошки в асфальт вызывает значительное перераспределение напряжений в гололедном слое на поверхности дорожного покрытия, что приводит к разрушению льда под воздействием колес проходящего транспорта [7]. Последнее справедливо для всех видов транспорта, в том числе для велосипедного. Поэтому применение асфальта с добавлением резиновой крошки может значительно увеличить продолжительность велосезона, в частности позволяя велосипедистам сравнительно безопасно ездить в конце октября - начале ноября, когда образующаяся наледь еще весьма неустойчива и может быть сравнительно легко раздавлена колесами. То же касается и периода с конца марта по начало апреля, когда снег уже в основном сходит, но велосипедному движению еще мешает наледь, образующаяся в результате ночных заморозков. Таким образом, применение асфальтобетона, модифицированного резиновой крошкой, позволяет осуществлять активное велосипедное движение почти на 2 месяца дольше, чем использование традиционного дорожного покрытия.

Важнейшим фактором для развития велосипедного движения является обеспечение его безопасности, так как велосипедисты являются уязвимыми участниками дорожного движения. Многочисленные опыты, проведенные в разных странах с покрытиями из асфальтобетона с добавлением резиновой крошки, показали, что количество ДТП со смертельным исходом на таких дорогах снижается на 50\%. Связано это с тем, что улучшенное сцепление колеса с таким покрытием ведет к снижению риска заносов и уменьшению величины тормозного пути транспортного средства. Недостатком асфальта с резиновой крошкой считается то обстоятельство, что он обладает повышенным сопротивлением качению колеса. Однако и этот факт может быть рассмотрен 
как положительный, когда речь идет о создании покрытия для объектов ВТИ. Особенно в случае с «велосипедными улицами», когда снижение скорости движения и тормозного пути, как велосипедов, так и автомобилей приводит к снижению риска аварийности и повышению уровня безопасности, прежде всего велосипедистов.

Положительно влияет на уровень безопасности движения и то, что у дорожного покрытия с добавлением резиновой крошки существенно снижаются светоотражающие свойства. Это ведет к улучшению видимости на дороге и снижению риска ослепления велосипедиста при избыточном освещении. И, как упомянуто выше, на снижении аварийности положительно сказывается увеличение срока службы и трещинностойкости дорожных покрытий.

Таким образом, доказано, что использование асфальта с добавлением резиновой крошки при строительстве объектов ВТИ целесообразно, а в ряде случаев даже необходимо. Мнение автора по разным типам объектов ВТИ представлено в таблице 2.

Таблица 2

Целесообразность применение асфальтобетона с добавлением резиновой крошки для разных типов ВТИ

\begin{tabular}{|c|c|}
\hline Тип ВТИ & Применение асфальта с резиновой крошкой \\
\hline 1 & на перекрестках по 150 метров с каждой стороны, крутых поворотах \\
\hline 2 & на перекрестках по 150 метров с каждой стороны, крутых поворотах, подъемах и спусках \\
\hline 3 & на всем протяжении \\
\hline 4 & на перекрестках по 150 метров с каждой стороны, крутых поворотах \\
\hline 5 & на всем протяжении \\
\hline 6 & на всем протяжении \\
\hline
\end{tabular}

Предлагается устраивать полностью из данного материала покрытие проезжей части велосипедных улиц, а также участков обычных велодорожек, изобилующих перекрестками или резкими поворотами, подъемами и спусками. Использование асфальта с резиновой крошкой при создании изолированных велодорожек и велопешеходных дорожек не представляется обязательным ввиду повышенной стоимости данного материала, но, тем не менее, без сомнения целесообразно, учитывая вышеописанные преимущества. 


\section{Литература:}

1. Галышев А. Б., Шелмаков С. В. Развитие велосипедного движения для улучшения экологической обстановки в крупных городах // Успехи современного естествознания. - Пенза, Академия естествознания. - 2011. №7. - 93 c. - ISSN 1681-7494.

2. Кадников, А. С., Иванов А. Ф. Применение резиновой крошки для повышения противогололедных свойств и устойчивости к колееобразованию асфальтобетонных покрытий // Техническое регулирование в транспортном строительстве. - 2015. - №2(10). С. 28-32.

3. Смирнов Н.В., Смирнов Б.М., Булгаков А.П. Использование резиновой крошки в наполнении битума для асфальтового покрытия автодорог. Аналитический обзор. СПб.: ООО «Новые технологии-инжиниринг», 2004. 17 c.

4. Трофименко Ю. В., Воронцов Ю М., Трофименко К. Ю. Утилизация автомобилей: Монография. - М.: АКПРЕСС, 2011. - 336 с.

5. Трофименко Ю. В., Воронцов Ю М., Трофименко К. Ю. Переработка и использование изношенных шин // Твердые бытовые отходы. - 2014. №3(93). - C. 42-49.

6. Использование резиновой крошки в дорожном строительстве [Электронный ресурс] // Cntomo.com: веб-сайт. - Текст. дан. - М., 2015. Дата обновления: 26.07.2015. - URL: http://www.cntomo.com/rezinovayakroshka-i-ee-primenenie/1105-ispolzovanie-rezinovoy-kroshki-v-dorozhnomstroitelstve.html (дата обращения: 30.05.2016).

7. Моисеев В. И., Козинов Г. Л., Старостин Г. И. Модель взаимодействия слоя гололеда с асфальторезиновым дорожным покрытием // Современные проблемы науки и образования. - 2012. - №2. - С. 248. 